Elsewhere it is known that a number of species attack one or other kind of migratory locust in the egg stage. Other Bombyliidæ parasitize the caterpillars of moths or the larvæ of solitary bees and fossorial wasps. Fabre, for example, gave an interesting account of a species that lives at the expense of the mason bee. One species has been bred from the puparia of tsetse flies (Glossina) and others are hyperparasites.

In Prof. Efflatoun's opinion the systematic arrangement of the Bombyliidæ still awaits a competent monographer, notwithstanding the labours of such authorities as Becker and Bezzi. The limits of some of the subfamilies are by no means well defined and the allocation of various genera is open to doubt. Possibly, as Bezzi originally suggested, a closer knowledge of the bionomics and ethnology of the family will lead to a better taxonomy. The Bombyliid fauna of Egypt, as with many othor families, undoubtedly forms, according to Prof. Efflatoun, a connecting link with the Palæarctic and Ethiopian zoogeographical regions.

A. D. Imms

\section{RECONSTRUCTION IN THE ASSAM HILLS}

$\mathrm{T}$ $\mathrm{HE}$ process of reconstruction must vary in different loc flifes, but in most cases the anthro. pologist can 1 ineal assistance. In his presidential address for 1945 to the Royal Anthropological Instifut of Great Britain and Ireland, Prof. J. H. Hitto discussed some problems of reconstruction as they will appear in the Assam Hills. Any hill-tribe tends to lead a more or less segregated life, and until this century the Nagas had had only sporadic communication with the outside world. The First World War was responsible for a certain amount of contact, but it was not until the recent campaign in their country that any large-scale opening-up occurred. Now there are good roads, and communication by air is also established.

Communications, with the labour necessary to maintain them, will mean a steady flow of money, in the form of wages, into the country ; and with the further opening-up of Burma and Assam, the Nagas will inevitably have to relinquish their position of isolation. Indeed, one curious result of the Japanese invasion was that it gave the Nagas a feeling of partnership with the other peoples who were fighting the common foe, and proved them most loyal and helpful to the Allies.

In return for this, it behoves us to see that the changes that have been wrought so suddenly should be beneficial and not detrimental to this fine race. They have an intense love of independence. They are asking for education; but it must be the right sort and benefit the whole community, rather than create a class of minor clerks who will try to exploit the less bookish members.

Another problem concerns the administration of the district : to what degree the Nagas are capable of indirect rule, and how far collective responsibility may be a workable proposition. Then, too, there is the language question, for example, whether the higher education should be given in English or Assamese; and if the latter, which of the several dialects should be used and reduced to writing. Cultivation of the hill country is another important question : removal of the forests reduces the rainfall necessary for the irrigation of the terraces which have replaced the tree-covered slopes, thus setting up a vicious circle from which there seems no escape since rice is a staple food.

These, then, are some of the problems of this area, a comparatively small one, and similar problems on a larger scale await solution in practically all south-east Asia, Indonesia and Oceania. The need for applied anthropology is unquestionable. Changes there are, and must increasingly be, and it is the duty of those responsible for administration to see that the welfare of indigenous peoples is the first consideration.

K. R.

\section{LAMARCK BICENTENARY CELEBRATIONS}

CELEBRATIONS in honour of the bicentenary 4 of the birth of Janarck were held in Paris during June 15-18 028 r the auspices of the Muséum National d'Hisłejrb Naturelle, the Société Zoologique de Frange fnd the Sgciété Botanique de France. A Holpentatives Bon Belgium, Denmark, Great Hiffin, Hollant, Mexico, Portugal and Switzerland. The proceedings started on June 15 by an inaugural session in the great amphitheatre of the Museum under the chairmanship of the Ministre de l'Education Nationale. The chief events in the life of Lamarck were traced by M. A. Urbain, director of the Museum ; M. H. Humbert spoke of Lamarck's contributions to botany, and M. R. Jeannel of his services to zoology; Prof. M. Caullery reviewed the significance of Lamarck's work from the point of evolution, and assessed the position which it oecupies to-day.

The morning of June 16 was devoted to a demonstration of exhibits relating to the life of Lamarck; a charming and interesting feature of the occasion was the presence of representatives of Lamarck's family, in the persons of his great-great-grandsons. A wreath was laid at the foot of Lamarck's statue, and the delegates then attended a banquet presided over by the Directeur des Rélations Culturelles of the Ministère des Affaires Ḱtrangères. In the afternoon the delegates were taken over the Musée de l'Homme by its founder and director, M. Rivet.

On June 17, the delegates were taken to the Zoological Park at Vincennes, where they had the opportunity of seeing many interesting animals and of learning of the difficulties encountered-and largely surmounted-in obtaining food for them. After enjoying the wonderful view from the top of the Grand Rocher, the delegates were entertained to luncheon by their hosts under the chairmanship of the Directeur de L'Enseignement Supérieur of the Ministère de L'Education Nationale. After returning to Paris the delegates attended a reception at the Laboratoire d'Evolution des Etre Organisés.

From this point, the programme was divided, and the delegates attended meetings of the Société Zoologique and of the Société Botanique, respectively, including demonstrations and communications.

The proceedings were marked by the greatest cordiality, and the trouble taken by the organisers in the face of considerable difficulties as regards food and accommodation was deeply appreciated by the visitors, who were very grateful for the opportunity to renew old friendships and make new ones while paying tribute to the name of Lamarck. 